\title{
Juvenile Probationers, Restitution Payments, and Empathy: An Evaluation of a Restorative Justice Based Program in Northeastern Pennsylvania
}

\author{
Sarah Kuehn ${ }^{1}$, John Yarnell ${ }^{2}$ and David R. Champion ${ }^{1, *}$ \\ ${ }^{1}$ Slippery Rock University; ${ }^{2}$ Wyoming and Sullivan County Probation Services, PA, USA

\begin{abstract}
Restitution programs are widely used to hold offenders accountable for their actions while providing restoration to victims and community service. However, compliance with restitution requirements is a major problem, as reported by juvenile probation offices across the country. The Firewood Program was developed for juvenile probationers in a rural Pennsylvania county to improve the completion rate of restitution payments to victims and provide community service. This study examines the effectiveness of the restitution program, which was measured as an
\end{abstract} \\ increase in the offender's level of empathy and shorter completion times of restitution payments.
}

Keywords: Restitution, community corrections, restorative justice, juvenile probation.

In recent decades, restorative justice emerged as a movement that challenged the traditional model of retribution by claiming that justice cannot be solely restored through the punishment of offenders. Instead of simply inflicting punishment on offenders, this movement recognized that more constructive alternatives, such as restoration to the victim and providing some service for the wider community, are critical to the overall spirit of justice (Johnstone \& Van Ness, 2007; Wenzel \& Thielmann, 2008). Although Restorative Justice (RJ) has experienced significant internal variation in both definition and specific approaches, it has gained popularity as a process and set of principles for responses to law-breaking and conflict.

Restorative Justice is generally viewed as an addition to, rather than a replacement of the traditional justice system. RJ based practices have gained in popularity, both in the U.S. and elsewhere. In the U.S., the practice of Restorative Justice has significantly increased (to a large extent) because of the implementation of the Balanced and Restorative Justice (BARJ) model set forth by the Office of Juvenile Justice and Delinquency Prevention (OJJDP) in several states. This model offers opportunity for juvenile offenders to build healthy relationships with others in the community and reach restorative resolutions through collaborative processes. Juvenile offenders are reintegrated into the community rather than excluded from it (as they would in a more retributive and punitive form of justice in the adult system). Section 6301(b)(2) of the Juvenile Act in Pennsylvania mandates that,

*Address correspondence to this author at the Department of Criminology, 016 Patterson Hall, Slippery Rock University, USA; Tel: (724) 738-4462; Fax: (724) 738-4822; E-mail: david.champion@sru.edu
Consistent with the protection of the public interest, to provide for children committing delinquent acts programs of supervision, care and rehabilitation which provide balanced attention to the protection of the community, the imposition of accountability for offenses committed and the development of competencies to enable children to become responsible and productive members of the community (Pennsylvania Juvenile Act, 1990, section 6301(b)(2)).

In addition to the BARJ principles of public safety and competency development, the third objective of the model is that juvenile offenders accept accountability for their actions, and actively work to repair the harm they caused to the victim and/or broader community. In general, this is approached through monetary payment towards victim restitution and the provision of general service to the community. The overall aim of this approach is to work towards the reintegration of offenders back into the community and repair harm to the victims.

The current study examines the effectiveness of the Firewood Program for juvenile probationers in a rural Northeastern Pennsylvania County, an initiative based on the BARJ model. Further, this study focuses on a relatively unexplored aspect of restorative justice: the element of empathy development in the process of offender treatment in the $\mathrm{RJ}$ model.

The firewood program aims to provide juvenile probationers with the opportunity to earn monies towards victim restitution payments in a timely manner; actively give back to the community, and increase their 
level of empathy for victims. In this work we review some of the salient literature on RJ (specifically, restitution and the role of empathy in offending patterns). We then describe the methodology of the current study and discuss the results, concluding by discussion implications for future research.

\section{RESTORATIVE JUSTICE, RESTITUTION, AND THE BARJ MODEL}

As noted above, RJ embodies a diverse set of principles and tends to lack a specific, universal definition. Restorative Justice can be implemented in several ways, and may have different meanings to different people (Johnstone \& Van Ness, 2007). The following quote describes the wide range of meanings under the umbrella term RJ:

Restorative justice has emerged in varied guises with different names, in many countries. It has sprung from sites of activism, academia and justice system. The concept may refer to an alternative process for resolving disputes, to alternative sanctioning options, or to a distinctly different, new model of criminal justice organised around principles of restoration to victims, offenders and the community in which they live. It may refer to diversion from formal court processes, to actions taken in parallel with court decisions, and to meetings between offenders and victims at any stage of the criminal process. (Daly \& Immarigeon, 1998, p. 21, quoted in Gavrielides, 2008, p. 166).

A restorative justice framework focuses on repairing the damage done to victims and the community through a process of negotiation, mediation, victim empowerment, and reparation (Zehr, 1995). In terms of justice and crime, it is not a specific program or a set of programs, but rather a new philosophy of justice that is based on the values of responsibility, inclusiveness, openness, trust, hope, and healing. Thereby, RJ can be placed on a continuum, ranging from fully restorative (i.e., the victim, the offender and the community are brought together) to traditional, adversarial processes, which may be based on $\mathrm{RJ}$ values, although they have not always been (e.g., probation, apologies to victims, restitution, and community service). It is important to note these nuances of RJ rather than applying a "black-and-white- option" as there exist "degrees of restorativeness" between fully and partly-restorative processes or programs that contain restorative elements (Walgrave, 2005, p. 5; Johnstone \& Van Ness, 2007; Zehr, 1995).

Another attempt to define $\mathrm{RJ}$ is to adopt a focus on outcomes or processes (Gavrielides, 2008; Johnstone \& Van Ness, 2007). Ideally, the whole process with all involved parties is based on voluntariness and deliberation, offering a "powerful sequence of social and moral emotions like shame, guilt, remorse, empathy, compassion, support, apology, and forgiveness in the offender, the victim, and other participants" (Walgrave, 2005, p. 4). However, these fully restorative processes are not always possible (for example, if the offender and victim do not agree on a face-to-face meeting). Nevertheless, the outcome of a typically non-restorative process might still be partially restorative even if obligations or sanctions are imposed, as long as they focus on reparation and restoration as well as putting an end to a conflict. Although the restorative impact may be reduced, practices such as restitution, compensation, or an apology to the victim are still more restorative than a complete lack of consideration for the victim coupled with retributive infliction of pain on the offender (Charbonneau, 2005; Johnstone \& Van Ness, 2007; Walgrave, 2005).

The growth in restitution programs within the United States has been significant. According to the Office of Juvenile Justice and Delinquency Prevention (OJJDP), over 400 new restitution programs have been initiated since 1986, and (perhaps more importantly) all of the programs which operated in 1986 were still in effect in a later 1991 survey (OJJDP, 1998). The overall restitution goal of these programs centers on the goal of holding an offender accountable for his or her actions while making amends to the victim of their crime for the damage or harm done (Schiff, 1998). A restorative justice paradigm considers restitution as a major part of the reparation process, as it attempts to restore the victim as well as the community to the state that existed before the offense was committed.

There have been numerous studies documenting the positive impact of RJ programs on victim and community satisfaction, offender recidivism, and perceptions of fairness (Bazemore \& Elis, 2007; Bergseth \& Bouffard, 2013; Braithwaite, 2002; Latimer, Dowden, \& Muise, 2005; Latimer \& Kleinknecht, 2000; Lipsey, 2009; Rodriguez, 2007; Ruback, Shaffer, \& Logue, 2004; Haynes, Cares, \& Ruback, 2014). In 
regards to restitution payments, one author reports a demonstrable link between restitution payments and offenders' recognition of their need to repair the harm they have caused (Van Vorrhis, 1985).

Similarly, an OJJDP study (1998) reports that when defendants are assigned community service and restitution as part of sentencing and successfully complete it, they recidivate at lower rates than those that failed to do so. These results also applied to programs that accepted more risky juvenile offenders. Similarly, Schneider, Schneider, Griffith, and Wilson (1982) found that juveniles who were ordered to pay restitution, either as part of a probation order or in lieu of incarceration for serious offenders, successfully completed their payments and had relatively low recidivism rates ( 8 and 14 percent after six months and one year, respectively. Butts and Snyder (1991) indicated similar results in their research; juveniles who participated in restitution programs had lower recidivism rates than those juveniles who were not ordered into restitution programs and instead solely received probation or placement as a sanction.

Further research has illustrated a strong association between the payment of restitution and the defendants' successful reintegration into society (Braithwaite, 1989). Weisheit, Wells, \& Falcone (1995) reported that counties with small populations have a greater likelihood of knowing someone on a personal basis that was a victim of a crime. These authors state that knowing the victim of a crime and understanding that defendants are ordered some type of restorative sanction tend to increase community satisfaction and support for restitution or other types of restorative sanctions. Other research has demonstrated improved psychological well-being for victims after receiving restitution payments (Tontodonato \& Erez, 1994).

Despite these positive outcomes, there is some research that indicates that restitution programs are ineffective. Lurigio and Davis (1990) point out that that some offenders may be unable to pay restitution. This especially applies to juveniles who, while having fewer financial obligations, have fewer actual or potential sources of income (Walsh, 2013). This limitation constitutes an important consideration for sentencing. Judges, when ordering restitution, must consider if the offender demonstrates characteristics (such as strong community ties, employment, school attendance, or no prior record) that would demonstrate an ability to comply with the restitution order (Davis, Smith, \& Hillenbrand, 1991; Ruback et al., 2004).
Haynes, Cares, and Ruback (2013) report that juveniles that paid a higher percentage of their restitution payments were less likely to get their probation revoked. However, the study further revealed that restitution was not always imposed, even when it was possible for the offenders to make compensation. Rather, fines were much more common, which lack a restorative impact (Haynes et al., 2013). Another implementation issue is that restitution payments may not be enforced, as it is unclear as to who is responsible for collecting, monitoring, and disbursing the restitution payments. This leads to low collection rates of restitution payments (Davis, Smith, \& Hillenbrand, 1991; Haynes et al., 2013; Ruback et al., 2004). In addition to these implementation issues, there have been other challenges facing restitution programs. For example, there is a concern that government agencies or other 'experts' will bureaucratize programs with standards, guidelines, and directives, which might have a negative effect on community specific programs developed to provide restoration to crime victims (Kurki, 1999).

The above mentioned concerns seem to be grounded in implementation challenges, rather than legitimate failures of the RJ principles and processes. For example, juveniles, who typically do not have an income, or indigent persons, who owe monies to victims, could be given opportunities to earn monies through community service in order to compensate victims for the harm that was done.

\section{THE ROLE OF EMPATHY IN OFFENDING PATTERNS}

While the RJ model is based on the idea of promoting restoration, it may also serve as the basis of a corrective strategy for the offender in terms of developing a greater sense of empathy through the process of participating in a restitution program that is grounded in RJ principles. The corrective aspect ideally would include assisting or guiding offenders to identify or increase genuine awareness that what they have done not only violated the law but also caused harm to the victim (Bazemore \& Maloney, 1994). However, there has been some debate in terms of defining empathy as a construct in the field of criminal justice studies. The most common definition is that in response to the emotional state of another person, individuals react in an effective manner in that they vicariously match or mirror the other person's emotions and exhibit emotional concern for their well-being (Eisenberg, 2000; Eisenberg \& Miller, 1987; Mehrabian \& Epstein, 1972). In addition to this broad definition, empathy has been divided into cognitive, emotional, 
and behavioral components (Broidy, Cauffman, Espelage, Mazerolle, \& Piquero, 2003). The cognitive aspect addresses the way an individual understands emotions of another person, mainly in terms of the perspective they take. Emotional empathy reflects the extent to which an individual understands or considers the consequences of their behavior for the overall wellbeing of other people or how their behavior would affect the feelings of others. Behavioral empathy is defined as the extent to how and what a person does to demonstrate benefiting others (Broidy et al., 2003).

Empathy has been considered central to moral development as it supports prosocial behavior and consideration of others, and fosters altruistic motivation to benefit others as opposed to antisocial, aggressive, or conduct disordered behavior (Eisenberg \& Miller, 1987). In fact, research has shown that those with higher levels of empathy are less likely to participate in delinquent behavior, and those who have little empathy for others are more likely to participate in anti-social or delinquent behavior (Broidy et al., 2003; Burke, 2001; Jolliffe \& Farrington, 2007). Offenders who are evaluated as psychopaths, for example, have low levels of empathy and are more likely to both have excessively violent offenses and to recidivate (Harpur, Hakstian, Ralph, \& Hare, 1988). Similar research has shown that there is an elevated risk for hostile behavior when emotional empathy is low in juveniles (Hunter, Figueredo, Becker, \& Malamuth, 2007).

Consequently, empathy-focused programs have been incorporated into many treatment approaches on the basis that participation in these programs will likely decrease recidivism rates (Mulloy, Smiley, \& Mawson, 1999). However, what has not been examined is whether or not an offender's participation in a program that is focused on actively restoring the victim through the payment of restitution and the providing community service will increase the offender's level of empathy in general. Furthermore, most prior studies on restitution programs have only examined adult offenders and there is limited (recent) research on juvenile restitution programs. The current study aims to address this gap in the literature through examining the BARJ based Firewood Program in a rural Northeastern Pennsylvania County.

\section{METHODOLOGY}

\section{The Firewood Program}

The Firewood Program is a relatively new program that focuses on juveniles processing firewood for sale to individuals. The juveniles split, stack, and deliver the firewood to members of the community earning restitution money for their victims. Juvenile probation reviews all cases and offers program participation to juvenile delinquents to complete their court ordered community service. Participation is completely voluntary. While there are no explicit inclusionary or exclusionary criteria such as type of offense or criminal history, juvenile probationers must be classified as low or medium risk on the Youth Level of Service/Case Management Inventory (YLS/CMI) to be accepted into the program. There are no additional psychological or diagnostic criteria specifically employed for the program, beyond the standard intake assessments for youths deemed appropriate for community supervision. The length of the program is typically between three and six months.

The program is advertised to the community primarily through prominent signage and word-ofmouth. Probationers have limited direct interaction with community members and act under the supervision of a county employee while engaged in the delivery of the firewood. However, the program does involve giving youths a skill set and basic job experience that may assist them in future employment opportunities.

The program was introduced to give juvenile probationers an opportunity to earn monies through community service in order to compensate victims for the harm that they caused. Prior to the implementation of the program, in many cases, juvenile's probation sentence had to be lengthened because of a failure to complete the ordered restitution payments. Also, the program was introduced to increase juveniles' awareness of their actions and the impact they had on others. Through program participation and community service, juveniles are being held responsible for their actions and are given the opportunity to actively repair the harm they caused: two critical concepts of restorative justice. The two main objectives of the Firewood Program are to (1) increase juvenile delinquents' compliance rates of restitution payments to victims and (2) raise juvenile levels of empathy by participating in a restorative justice program. The focus of the current study is to examine if these two objectives, which are both elements of the BARJ model, are being achieved.

\section{Hypotheses}

This study had two hypotheses. Hypothesis 1 states that County A juveniles, who participated in the 
Firewood Program, would complete the restitution requirements in a shorter period of time than County $B$ juveniles, who served probation and were ordered to make restitution, but did not participate in a RJ based restitution program. Hypothesis 2 states that the empathy scores of juveniles from County $A$ would be increased after the completion of the program. While the first hypothesis tested the difference between the two different groups (County A and B), the second hypothesis was tested utilizing a pre/ post-test design that compares juveniles' empathy scores in County A before and after program completion.

\section{Sample}

Both groups of juveniles were from two rural counties in Northeastern Pennsylvania. They were both within the same judicial district and had a comparable population size, population demographics, and crime rates. County $A$ subjects participated in the Firewood program to make restitution (in addition to their probationary sentences), whereas County B juveniles served regular probation with restitution orders and did not have access to the program. The total sample size of this study was 52 juvenile probationers (26 from each county). From authorized access to court records, we matched participants from both counties in terms of gender, ethnicity, age, YLS/CMI score, and criminal history to allow for a group comparison. There was no mandated time limit for completing the restitution payments, but they needed to be paid in full before juveniles could successfully complete their probation sentence.

\section{Measures}

The current study examines two variables: 1) length of time to complete restitution requirements and 2) level of emotional empathy exhibited by juvenile delinquents before and after program completion. The restitution amount was established by the courts based on the degree of loss attributed to the victims. Juveniles were placed on probation for as long as needed up to age 21. The length of time it took to complete restitution requirements was measured in number of days from the date probation was issued to the completion date of restitution requirements.

Emotional empathy was measured using the Balanced Emotional Empathy Scale (BEES), which defines emotional empathy 'a vicarious emotional response to the perceived emotional experiences of others' (Mehrabian, 1997, p. 525). The BEES consists of 30 items based on a 9 point Likert scale, ranging from - 4 (very strong disagreement) to +4 (very strong agreement). Respondents are asked to indicate the degree of agreement or disagreement with each of the items. Examples of items include, 'Unhappy movie endings haunt me for hours afterward' or 'I cannot feel much sorrow for those who are responsible for their own misery.' Half of the items are positively worded and positively scored and the remaining items are negatively worded and scored to avoid respondents' acquiescence bias. The total positive values are subtracted by the total negative values and the raw score is consequently obtained. Based on the raw score, a standardized $z$ score can be obtained and a level of empathy can be determined. Mehrabian (1997) established the norms for the assessment to have a mean score of 45 and a standard deviation of 24 , with an internal reliability coefficient (Cronbach's alpha) of 87 .

\section{Analyses}

To test hypothesis 1 , an independent sample t-test was conducted to examine if there was a significant difference between the mean number of days it took to complete restitution requirements between juveniles from County A and B. Further, Hypothesis 2 sought to determine if there was a significant difference in the juvenile's mean level of emotional empathy before beginning the restitution Firewood Program and following the completion of the program by using a dependent t-test, pre-test and post-test design. To reiterate, the latter hypothesis was only tested using County A juveniles.

\section{RESULTS}

\section{Sample Demographics}

The sample demographics are presented in Table 1. The total number of participants in this study including both groups was 52 (26 in each sample). Since the two groups were matched in terms of their demographics, the gender ratio $(76.9 \%$ males and $23.1 \%$ females) and ethnicity (all Caucasian) were the same for both samples. The ages ranged from 12 to 17 years with a mean of 15 for both groups.

Furthermore, both groups were comparable in terms of their criminal history and seriousness of their current offense (Table 2). Seven juveniles of each group had been previously arrested. Of those, only two in County $A$ and one in County B had been arrested twice before. 
All others had only one previous arrest for offenses such as possession of illegal substances, theft, criminal trespassing, and burglary.

Table 1: Sample Demographics

\begin{tabular}{|c|c|c|}
\hline & County A & County B \\
\hline \multicolumn{3}{|l|}{ Gender } \\
\hline Female & $6(23.1 \%)$ & $6(23.1 \%)$ \\
\hline Male & 20 (76.9\%) & 20 (76.9\%) \\
\hline Mean age $(12-17)$ & 14.96 & 15.04 \\
\hline
\end{tabular}

Except for two juveniles who had two current offenses, all juveniles had one current offense. The types of current offenses for both groups were similar, with the majority of offenses being misdemeanors. The most frequent type of offenses for both groups was theft $(38.5 \%$ and $46.2 \%$ for County $A$ and B, respectively), followed by burglary (26.9\% and $23.1 \%$ for County $A$ and $B$, respectively). The three other offense types were criminal trespassing, vandalism, and access device fraud.

\section{Comparison of Restitution Payments}

An independent $t$ test was conducted to determine if there was a significant difference between the numbers of days it took for County B delinquents and County A delinquents who participated in the Firewood Program to complete restitution requirements.

As indicated above, there was no set time by the court to complete the restitution payments. The results of the analysis indicate that the County $B$ delinquents took significantly longer to complete restitution requirements ( $M=197.8$ days) than the County $\mathrm{A}$ delinquents ( $M=140.423$ days) (Table 3 ), even though County B delinquents had, on average, a lower restitution amount $(\$ 385.12)$ than County A delinquents (\$429.87).

\section{Comparison of Emotional Empathy Scores Pre and Post Completion of the Program}

A dependent $t$ test was conducted to determine if there was a statistical difference between the emotional empathy scores as measured by the BEES administered to the County $A$ delinquents prior to beginning the restitution Firewood Program and the scores obtained following their completion of the program. To reiterate, this comparison only included County A participant pre/post program completion. The results of the analysis indicate that the emotional empathy scores significantly increased following the completion of the restitution program (Table 4). More specifically, the pretest raw scores $\left(\bar{x}_{1}=65.808\right)$ were lower than the post-test raw scores $\left(\bar{x}_{2}=70.731\right)$. The difference between the two means was statistically

Table 2: Criminal History and Current Offense

\begin{tabular}{|c|c|c|c|c|}
\hline & \multicolumn{2}{|c|}{ County A } & \multicolumn{2}{|c|}{ County B } \\
\hline Mean \# of previous arrests & 1.3 & & 1.1 & \\
\hline \multicolumn{5}{|l|}{ Type of offense previous arrest } \\
\hline Possession of illegal substance & 4 & $(15.4 \%)$ & 0 & $(0.0 \%)$ \\
\hline Theft & 1 & $(3.9 \%)$ & 4 & $(15.4 \%)$ \\
\hline Criminal trespassing & 1 & $(3.9 \%)$ & 2 & $(7.7 \%)$ \\
\hline Burglary & 1 & $(3.9 \%)$ & 1 & $(3.9 \%)$ \\
\hline Previously been on probation (yes) & 6 & $(23.1 \%)$ & 7 & $(26.9 \%)$ \\
\hline \multicolumn{5}{|l|}{ Current offense } \\
\hline Felony & 12 & $(46.2 \%)$ & 12 & $(46.2 \%)$ \\
\hline Misdemeanor & 14 & $(53.8 \%)$ & 14 & $(53.8 \%)$ \\
\hline \multicolumn{5}{|l|}{ Type of current offense } \\
\hline Theft & 10 & $(38.5 \%)$ & 12 & $(46.2 \%)$ \\
\hline Burglary & 7 & $(26.9 \%)$ & 6 & $(23.1 \%)$ \\
\hline Criminal trespassing & 2 & $(7.7 \%)$ & 4 & $(15.4 \%)$ \\
\hline Vandalism & 5 & $(19.2 \%)$ & 2 & $(7.7 \%)$ \\
\hline Access device fraud & 2 & $(7.7 \%)$ & 2 & $(7.7 \%)$ \\
\hline
\end{tabular}


Table 3: Group Comparison of Time to Complete Restitution Requirements

\begin{tabular}{|c|c|c|c|c|c|c|c|c|c|}
\hline & Mean (days) & $\boldsymbol{N}$ & SD & SEM & Mean Diff. & SE & t & df & Sig. \\
\hline \hline County B & 197.8 & 26 & 101.13 & 19.83 & \multirow{2}{*}{57.39} & 25.2 & 27.25 & 50 & .027 \\
\hline County A & 140.4 & 26 & 79.43 & 15.58 & & & \\
\hline
\end{tabular}

Table 4: Empathy Scores before and after Program Participation

\begin{tabular}{|c|c|c|c|c|c|c|}
\hline Empathy Score & $\mathbf{N}$ & $\bar{x}$ & $\mathbf{t}$ & SD & df & Sig. \\
\hline Before Program Participation & 26 & 65.808 & \multirow{2}{*}{-7.177} & \multirow{2}{*}{3.498} & \multirow{2}{*}{25} & \multirow{2}{*}{.000} \\
\hline After Program Participation & 26 & 70.731 & & & & \\
\hline
\end{tabular}

significant at the alpha level of $.001(t=-7.177)$. This overall increase in the emotional empathy scores pre and post program completion also applied to all individual scores of the participants.

\section{DISCUSSION}

There have been many restitution programs implemented across the United States that are based on the philosophy of the restorative justice model. The Firewood Program in a Northeastern Pennsylvania county is one such program, which utilizes the community service of chopping and preparing firewood to restore the financial damage of victims of crimes committed by juvenile delinquents. The present study examined the effectiveness of the Firewood Program, which is based on the principles of the restorative justice, particularly in terms of restitution payments and ability to improve victim empathy through the process of participation in such a program.

Both hypotheses were supported following the analysis of the data collected from the experimental group of delinquents who participated in the Firewood Program and the control group of juvenile delinquents who did not participate in such a program. The first hypothesis stated that participation in the restitution program would minimize the length of time it took for delinquents to complete their restitution requirements, i.e., repaying victims the monetary amounts owed. The results indicate that it took juveniles participating in the Firewood Program significantly less time to complete the restitution payments and fulfilling their monetary obligation to their victims. The program provided juveniles with the means to make money, which they may not have been able to earn otherwise. It is also asserted that their program participation enables juveniles to understand the relationship between the amount of hours worked and money earned, which, in turn, helped them appreciate the amount of harm they caused and their responsibility to repair it. This last is only speculation, however, and was not directly tested in the current study.

The second hypothesis, that participation in the Firewood Program would increase the delinquents' level of empathy, is also supported by this study. The results show that the mean empathy score for all participants was significantly higher following the completion of the program than the mean empathy score obtained prior to beginning the program. All participants demonstrated an increase in their ratings of items on the assessment of empathy. Consequently, the Firewood program indeed appeared to influence the participants' empathetic regard for others. Again, we may cautiously postulate that the active participation in a restitution program likely raised juvenile's understanding of their behavior and its impact on others as well as made them recognize their responsibility to repair the harm caused.

Although the hypotheses were supported in this study, it should be noted that the Firewood program is not a pure RJ approach. It contains some traditional, adversarial notions (e.g., the victim and the offender do not directly communicate with each other and while program participation is voluntary, community service is part of a mandated court order). Therefore, although these results support some of the central tenets of the $\mathrm{RJ}$ model, they do not reflect the testing of a pure $\mathrm{RJ}$ program. For future implementation of the program, a more collaborative process involving victims might be considered to increase the restorative impact of the program and victim satisfaction.

When discussing these results, however, it is important to note that RJ based programs such as the Firewood program, which mainly focus on the victim and repairing the harm, are unable to address the 
underlying causes of crime and prevent future offenses. As Umbreit (1994) has commented, 'it is naïve to think that a time-limited intervention such as mediation itself...would be likely to have a dramatic effect on altering criminal and delinquent behaviour' (quoted in Hayes, 2007, p. 436). Some types of juvenile offenders require multi-level interventions and services, which cannot be provided by a communitybased conference or restitution payment without compromising public safety (Corrado, Cohen, \& Odgers, 2003). In the case of the Firewood participants, who scored only low to medium on the YLS, these multi-level interventions and services did not seem necessary. Therefore, the program provides an opportunity to supplement the traditional justice system (in this case standard juvenile probation) with RJ principles and processes.

These results support other promising research results on RJ processes. However, further evaluative research regarding $\mathrm{RJ}$ based programs and processes within the criminal justice system is needed. Further, the studies that do exist produce, to some extent, inconsistent results and many surveys are subject to methodological shortcomings. For instance, one shortcoming is the problem self-selection, i.e., when victims and offenders are given the choice to participate instead of randomized samples and control groups to compare RJ and traditional court processes (Bazemore \& Elis, 2007; McCold, 2003; Rodriguez, 2007; Wenzel et al., 2008). Another concern is lack of valid and reliable effectiveness measures to evaluate RJ intervention, and many studies show inconsistent outcomes (i.e. some studies show no difference, higher and lower recidivism rates when comparing offenders who have participated in RJ processes compared to traditional court processes), depending on the type of offenses and contexts (Corrado et al., 2003; McCold, 2003; Rodriguez, 2007).

Despite these inconsistent results, the overall results show that RJ programs can work and produce more satisfying outcomes for both the offender and the victim than traditional and more retributive justice processes if implemented correctly (e.g., appropriate types of offenders and offenses). There are also no indications for negative impacts on public safety and recidivism (Walgrave, 2005). In effect, victims show high satisfaction rates, mostly due to their active involvement in the process (McCold, 2003; Rugge \& Cornier, 200; Walgrave, 2005; Wenzel et al., 2008). Specifically, in regards to restitution, Haynes et al.'s (2013) study indicates that there is great potential to more frequently sentence juvenile offenders to restitution payments to help them understand the impact of their actions on others and actively repair the harm they caused.

\section{LIMITATIONS}

This study is necessarily limited in scope and generalizability due to sample size and to the nature of offender admitted to the program. The former is due to the relative youth of the program and demographic features of the counties. The latter is due to the courtmandated limits regarding the eligibility of offenders to participate in the program.

Although all delinquents who participated in the Firewood Program were included in the analysis for this study (and there were no exclusions based on race, sex, or any other characteristic), the number of participants was considerably low. In addition, there were several characteristics of the participants that need to be taken in to account when interpreting the results. All participants were white and were the product of low socio-economic status. It is therefore possible that the exclusion of other racial groups, as well as participants with a more varied socio-economic status, would have influenced the results.

Another limitation for the generalizability of the results is the type of delinquents participating in the program. Only low to medium risk of offenders were admitted to the program. There were no participants in the study that were in placement or detained for violent or criminal activity requiring a higher level of detention or supervision. Furthermore, there were no participants included in this study that had significant mental health problems or posed as a behavioral management risk. It is thus possible that the inclusion of individuals presenting with more severe problems such as antisocial personality traits, conduct disorder, psychotic disorders, and/or extremely low levels of empathy may have affected the results of this study, particularly in terms of the pre/post empathy scores.

It is also possible that demand characteristics played a role in the participants' responses, particularly with regard to the inflation of the degree of empathetic reactions to the items on the BEES. For example, as the delinquents who participated in the Firewood Program were administered the BEES twice by a probation officer, it is conceivable that the pressure or expectation to present as more empathetic may have influenced their responses. In addition, practice effects 
may have also played a role in results and influenced the difference between the pre and posttest of the BEES. In general, three to six months passed between the pretest administration of the BEES and the posttest administration. Therefore, it is possible that participants may have recalled the items and how they responded, and consequently inflated their responses to demonstrate their individual improvement, particularly in the presence of the probation officer.

Another demographic limitation of the study was that there was a disproportionate amount of males to females in the study. Twenty out of the twenty-six participants in each group were male. Since there were a large proportion of males in the study, it may have influenced empathy scores, specifically in terms of the degree of empathy expressed as well as experienced in general. Past research has indicated that females typically exhibit a higher level of emotional empathy than their male counterparts because they endorsed items more strongly in terms of their level of emotional empathy (Mehrabian, Young, \& Stato, 1988). It may therefore be more accurate to study males and females separately, especially when establishing norms with different populations, to reach more generalizable results.

\section{CONCLUSION AND FUTURE DIRECTIONS}

In terms of future directions and strategies for replication there are several considerations for future research studies. One direction is to evaluate male and female delinquents for differences in restitution compliance and level of expressed empathy. Also, since the sample size was small, it is suggested that the study be replicated with a larger sample, including more diversity in terms of race, gender, socioeconomic status, and geographic areas. In addition, future studies could also include assessment of empathy and restitution compliance with delinquents who require a higher level of supervision due to their severity of criminal activity or presence of significant pathology. Further, variables such as the motivation to succeed and to complete restitution payments should also be included in further research. It is possible that this motivation is part of the desire to participate in such a RJ based program and could thus explain the difference in outcomes rather than the participation in the program.

Another research avenue would be a qualitative investigation. The Firewood program is relatively new and would likely benefit from a re-evaluation of its effectiveness and program refinement. Structured or semi-structured interviews specifically asking delinquents what they valued about the restitution program and what they gained through their participation in regards of the human impact of their crimes. Input from probation officers, community members, and, especially, victims, might also improve the effectiveness of the program.

A final recommendation would be to conduct a longitudinal investigation examining recidivism rates for those juveniles who participated in the present study. The goal of restorative justice is to restore victims and make offender more aware of their actions and costs to the victims and broader community. Obtaining data on juvenile's re-offending rates would be helpful to establish the effectiveness of the Firewood and similar $\mathrm{RJ}$ based programs in terms of public safety.

Generally, RJ evaluations should assist in developing 'best practices' and develop beyond a process that "remains more an art form than a science" (McCold, 2003, p. 370). One also needs to be aware that the fundamental principles and values of restorative justice are somewhat incompatible with the traditional methods of measuring success. The main goals of restorative justice are more abstract and intangible, making the measurement of success difficult. Reducing the success measures of restorative justice to recidivism, participant satisfaction, and service delivery criteria (e.g. number of agreements completed), however, is a misunderstanding of the vision it attempts to accomplish. The objectives of repairing harm, restoring justice, ensuring accountability and responsibility of offenders, skill building, and strengthening communities are equally important (Bazemore \& Elis, 2007, p. 398; Johnstone \& Van Ness, 2007). Unfortunately, these objectives make an evaluation more difficult as concrete, scientific methods of measuring the success of such goals are still being developed. Equally important in terms of evaluation research should be the questions as to why RJ programs work and how they achieve positive outcomes (Bazemore \& Elis, 2007). ${ }^{1}$

Conclusively, RJ based approaches alone will not solve juvenile crime and the often complex underlying causes thereof. Still, RJ offers a new vision of justice and conflict resolution. Both the rehabilitative

${ }^{1}$ For a more detailed discussion of the challenges and future direction of evaluating RJ programs, see Bazemore and Elis (2007), Hayes (2007), Presser \& Van Voorhis (2002), and Rodriguez (2007). 
(treatment) and punitive (harsh sentences and supervision) approaches not only place offenders in a passive role and detract from the ability to make amends, but they also tend take the conflict and harm to an abstract level. That is, these traditional models tend to be detached from the real problems of victim, offenders, and communities (Zehr, 1995). In contrast, and as demonstrated in this study, the implementation of (partial) RJ based approaches can particularly enhance the juvenile justice system by providing a more holistic and community-based resolution to crime. This approach would hold juvenile delinquents accountable for repairing the harm they caused to their victims through their actions; enable them to lessen the stigmatization of their offender status; promote reintegration, and elevate the role of victims and communities in the criminal justice process.

\section{REFERENCES}

Bazemore, G. \& Elis, L. (2007). Evaluation of restorative justice. In Johnstone, G. and Van Ness, D. (Eds.), Handbook of restorative justice (pp. 397- 425). Willian Publishing.

Bazemore, G \& Maloney, D. (1994). Rehabilitating community service toward restorative service sanctions in a balanced system. Federal Probation, 58(1), 24-35. Retrieved from: http://www.uscourts.gov/FederalCourts/ProbationPretrialServ ices/FederalProbationJournal.aspx

Bergseth, K. \& Bouffard, J. (2013). Examining the effectiveness of a restorative justice program for various types of juvenile offenders. International Journal of Offender Therapy and Comparative Criminology, 57(9), 1054-1075. http://dx.doi.org/10.1177/0306624X12453551

Braithwaite, J. (1989). Crime, shame, and reintegration. Cambridge, UK: Cambridge University Press. http://dx.doi.org/10.1017/CBO9780511804618

Braithwaite, J. (2002). Restorative justice and responsive regulation. New York: Cambridge University Press.

Broidy, L., Cauffman, E., Espelage, D. L., Mazerolle, P., \& Piquero, A. (2003). Sex differences in empathy and its relation to juvenile offending. Violence and Victims, 18(5), 503-516. http://dx.doi.org/10.1891/vivi.2003.18.5.503

Burke, D. (2001). Empathy in sexually offending and non-offending adolescent males. Journal of Interpersonal Violence, 16(3), 222-233. http://dx.doi.org/10.1177/088626001016003003

Butts, J. \& Snyder, H. (1991). Restitution and juvenile recidivism. Monograph: Pittsburgh, PA: National Center for Juvenile Justice.

Bush, C., Mullis, R., \& Mullis, A. (2000). Differences in empathy between offender and nonoffender youth. Journal of Youth and Adolescence, 29(4), 467-478.

http://dx.doi.org/10.1023/A:1005162526769

Corrado, R., Cohen, I., \& Odgers, C. (2003). Multi-problem violent youth: A challenge for the restorative justice paradigm. In $\mathrm{E}$. Weitekamp \& H. Kerner (eds.), Restorative justice in context: International practice and directions (pp. 1-22). Willan Publishing.

Daly, K. \& Immarigeon, R. (1998). The past, present, and future of restorative justice: Some critical reflections. Contemporary Justice Review, 1(1), 21-45. doi:10.1177/1462474022222 8464
Davis, R., Smith, D., \& Hillenbrand, S. (1991). Increasing offender compliance with restitution orders. Judicature, 74(5), 245248. Retrieved from https://www.ajs.org/judicature-journal/

Eisenberg, N. (2000). Emotion, regulation, and moral development. Annual Review of Psychology, 51, 665-697. Retrieved from http://www.annualreviews.org/journal/psych http://dx.doi.org/10.1146/annurev.psych.51.1.665

Eisenberg, N., \& Miller, P.A. (1987). The relation of empathy to prosocial and related behaviors. Psychological Bulletin, 101(1), 91-119. http://dx.doi.org/10.1037/0033-2909.101.1.91

Gavrielides, T. (2008). Restorative justice: The perplexing concept: Conceptual fault-lines and power battles within the restorative justice movement. Criminology and Criminal Justice, 8(2), 165- 183. http://dx.doi.org/10.1177/17488895808088993

Harpur, T., Hakstian, A., Ralph, A., \& Hare, R. (1988). Factor Structure of the Psychopathy Checklist. Journal of Consulting and Clinical Psychology, 56(5), 741-747. http://dx.doi.org/10.1037/0022-006X.56.5.741

Hayes, H. (2007). Reoffending and restorative justice. In Johnstone, G. and Van Ness, D. (Eds.), Handbook of restorative justice (pp. 426-444). Willian Publishing.

Haynes, S., Cares, A., \& Ruback, R. (2013). Juvenile economic sanctions: An analysis of their imposition, payment, and effect on recidivism. Criminology and Public Policy, 13(1), 3169. http://dx.doi.org/10.1111/1745-9133.12063

Hunter, J., Figueredo, A., Becker, J., \& Malamuth, N. (2007). NonSexual Delinquency in Juvenile Sexual Offenders: The Mediating and Moderating Influences of Emotional Empathy. Journal of Family Violence, 22, 43-54. http://dx.doi.org/10.1007/s10896-006-9056-9

Johnstone, G. \& Van Ness, D. (2007). The meaning of restorative justice. In Johnstone, G. and Van Ness, D. (Eds.), Handbook of restorative justice (pp. 5-23). Willian Publishing.

Jolliffe, D., \& Farrington, D. (2007). Examining the relationship between low empathy and self-reported offending. Legal and Criminological Psychology, 12(2), 265-286. http://dx.doi.org/10.1348/135532506X147413

Kurki, L. (1999). Incorporating restorative and community justice into American sentencing and corrections. Retrieved from: U.S. Department of Justice website: https://www.ncjrs.gov/pdffiles1/nij/175723.pdf

Latimer, J., Dowden, C., \& Muise, D. (2005). The effectiveness of restorative justice practice: A meta-analysis. Prison Journal, 85(2), 127-144. http://dx.doi.org/10.1177/0032885505276969

Latimer, J. \& Kleinknecht, S. (2000). The effects of restorative justice programming: A review of the empirical research. Department of Justice Canada, Research and Statistics Division: Ottawa, Ontario. Retrieved from: http://www.justice.gc.ca/eng/rp-pr/csj-sjc/jspsjp/rr00_16/rr00_16.pdf

LeSure-Lester, G. (2000). Relation between empathy and aggression and behavior compliance among abused group home youth. Child Psychiatry and Human Development, 31(2), 153-161. http://dx.doi.org/10.1023/A:1001900727156

Lipsey, M. (2009). The primary factors that characterize effective interventions with juvenile offenders: A meta-analytic overview. Victims \& Offenders, 4, 124-147. http://dx.doi.org/10.1080/15564880802612573

Lurigio, A. \& Davis, R. (1990). Does a threatening letter increase compliance with restitution orders? A field experiment. Crime \& Delinquency, 36(4), 537-548. http://dx.doi.org/10.1177/0011128790036004007

McCold, P. (2003). A survey of assessment research on mediation and conferencing. In Walgrave, L. (Ed.). Repositioning 
restorative justice (pp. 65-67). United Kingdom: Willian Publishing.

Mehrabian, A., \& Epstein, N. (1972). A measure of emotional empathy. Journal of Personality, 40(4), 525- 543. http://dx.doi.org/10.1111/j.1467-6494.1972.tb00078.x

Mehrabian, A. (1997). Analysis of affiliation-related traits in terms of the PAD temperament model. Journal of Psychology, 131(1), 101-117. http://dx.doi.org/10.1080/00223989709603508

Mehrabian, A. (2000). Manual for the Balanced Emotional Empathy Scale (BEES). University of California, Los Angeles.

Mulloy, R., Smiley, W., \& Mawson, D. (1999). The impact of empathy training on offender treatment. Forum on Corrections Research, 11(1). Retrieved from: http://www.csccc.gc.ca/publications/forum/e111/e111d-eng.shtml

Office of Juvenile Justice and Delinquency Prevention (1998). Restitution education, specialized training, and technical assistance (RESTTA) National Directory of Restitution and Community Service Programs (Report No. NCJ 166365). Retrieved from http://www.ojjdp.gov/pubs/restta/

Pennsylvania Juvenile Act (1990). Juvenile matters. Retrieved from http://www.legis.state.pa.us/WU01/LI/LI/CT/HTM/42/00.063.. HTM

Presser, L. \& Van Voorhis, P. (2002). Values and evaluation: Assessing processes and outcomes of restorative justice programs. Crime and Delinquency, 48(1), 162-187. http://dx.doi.org/10.1177/0011128702048001007

Price, M. (2001). Personalizing crime: Mediation produces restorative justice for victims and offenders. Dispute Resolution Magazine, Fall 2001. American Bar Association. Retrieved from: http://www.vorp.com/articles/justice.html

Rodriguez, N. (2007). Restorative justice at work: Examining the impact of restorative justice resolutions on juvenile recidivism. Crime \& Delinquency, 53(3), 355-379. http://dx.doi.org/10.1177/0011128705285983

Rowley, M. (1990). Comparison of recidivism rates for delinquents processed in a restitution diversion program to a matched sample processed in court. In Galaway, B. \& Hudson, J. (Eds.), Criminal justice, restitution, and reconciliation (pp. 217-226). Monsey, NY: Criminal Justice Press.

Ruback, R., Shaffer, J., \& Logue, M. (2004). The imposition and effects of restitution in four Pennsylvania counties: Effects of size of county and specialized collection units. Crime \& Delinquency, 50(2), 168-174 http://dx.doi.org/10.1177/0011128703258943

Schiff, M. (1998). Restorative Justice Interventions for Juvenile Offenders. A Research Agenda for the Next Decade. Western Criminology Review, 1(1), 1-20. Retrieved from: https://wcr.sonoma.edu/v1n1/schiff.html
Schneider, P., Schneider, A., Griffith, W, \& Wilson, M. (1982). Two year report on the National Evaluation of Juvenile Restitution Initiative: An overview of program performance. Institute of Policy Analysis. Retrieved from https://www.ncjrs.gov/App/ Publications/abstract.aspx? ID $=86676$

Shapiro, J., Morrison, E., \& Boker, J. (2004). Teaching empathy to first year medical students: Evaluation of an elective literature and medicine course. Education for Health: Change in Learning and Practice, 17(1), 73-84. http://dx.doi.org/10.1080/13576280310001656196

Singer, T., Seymour, B., O’Doherty, J., Kaube, H., Dolan, R., \& Frith, C. (2004). Empathy for pain involves the affective but not sensory components of pain. Science, 303, 1157-1162. Retrieved from: http://www.sciencemag.org/journal http://dx.doi.org/10.1126/science. 1093535

Sudipta, R. (1990). Offender-oriented restitution bills: Bringing total justice for victims? Federal Probation, 54(3), 30-36. Retrieved from http://www.uscourts.gov/FederalCourts/ ProbationPretrialServices/FederalProbationJournal.aspx

Tontodonato, P. \& Erez, E. (1994). Crime, Punishment, and Victim Distress. International Review of Victimology, 3, 33-55. doi:10.1177/026975809400300203.

Umbreit, M. (1989). Crime victims seeking fairness, not revenge. Toward restorative justice. Federal Probation, 53(3), 52-57. Retrieved from: https://www.ncjrs.gov/App/Publications/ abstract.aspx? ID=119864

Van Ness, D. (1990). Legal issues of restorative justice. In Bazemore, G. \& Walgrave (Eds.), Restorative justice and repairing the harm of youth crime (pp. 263-284). Monsey, NY: Criminal Justice Press.

Van Ness, D. \& Strong, K. (1997). Restoring justice. Cincinnati, OH: Anderson.

Van Vorrhis, P. (1985). Restitution outcome and probationer's assessment of restitution: The effect of moral development. Criminal Justice and Behavior, 12(3), 259-287. http://dx.doi.org/10.1177/0093854885012003001

Walsh, T. (2013). Juvenile economic sanctions. A logical alternative? Criminology and Public Policy, 13(1), 69-77. http://dx.doi.org/10.1111/1745-9133.12070

Weisheit, R., Wells, L., \& Falcone, D. (1995). Crime and Policing in Rural and Town America: An Overview of the Issues. Washington D.C.: Bureau of Justice Statistics. Retrieved from: https://www.ncjrs.gov/txtfiles/crimepol.txt

Wenzel, M., and Thielmann, I. (2006). Why we punish in the name of justice: Just desert versus value restoration and the role of social identity. Social Justice Research, 19(4), 450-470. http://dx.doi.org/10.1007/s11211-006-0028-2

Zehr, H. (1995). Changing lenses: A new focus for crime and justice. Scottdale, PA: Herald.

\section{DOI: http://dx.doi.org/10.6000/1929-4409.2014.03.32}

(C) 2014 Kuehn et al.; Licensee Lifescience Global.

This is an open access article licensed under the terms of the Creative Commons Attribution Non-Commercial License (http://creativecommons.org/licenses/by-nc/3.0/) which permits unrestricted, non-commercial use, distribution and reproduction in any medium, provided the work is properly cited. 